\title{
Methods for Rooting of Larch Cuttings and Application in Clonal Selection
}

\author{
by
}

E.K. Morgenstern ${ }^{1}$

\begin{abstract}
Based on experiments with Larix laricina (Du Roi) $\mathrm{K}$. Koch, environments and treatments are described that achieved good rooting, overwintering and subsequent development. Cuttings rooted best if taken from seedlings 3-6 years old during the last week of July, when lignification begins at the base of newly formed shoots. Overwintering in sealed, cold greenhouses or open shade-halls is possible during the first winter if the rooted cuttings are hardened off for at least 4 weeks before mid-November. Clonal selection at the age of 6 years for stem straightness appears to be possible.
\end{abstract}

Key words: Vegetative propagation, age, season, rooting chamber, overwintering, stem straightness.

\section{Résume}

On décrit des environnements et des traitements qui donnent des bons résultats pour l'enracinement, I'hivernage, et le développement ultérieur de boutures lors d'essais avec Larix laricina (Du Roi) K. Koch. La formation de racines est meilleure si les boutures sont prélevées au cours de la dernière semaine de juillet, lorsque la lignification débute à la base des nouvelles pousses, sur des semis agés de 3 à 6 ans. L'hivernage dans des serres froides scellées ou sous une ombrière est possible durant le premier hiver si l'endurcissement des boutures enracinées débute au moins 4 semaines avant la mi-novembre. La sélection de clone pour la rectitude de la tige semble possible dès l'âge de 6 ans.

Mots-clés: propagation végétative, âge, saison, chambre d'enracinement, hivernage, rectitude de la tige.

\section{Introduction}

Vegetative propagation of plants is not new but has been practiced for many centuries. In his "Historia naturalis", Plinius described layering of trees in 76 A.D., and a German forester, Pfifferling, rooted cuttings of Norway spruce (Picea abies [L.] Karst) in 1825 (Kleinschmit 1975). In Canada, the application of plant hormones to stimulate root formation in conifer cuttings was pioneered at the Petawawa Forest Experiment Station in Ontario during the 1930s (Farrar 1939).

Among the several techniques of vegetative propagation - grafting, budding, layering and rooting - rooting is most widely used. In silviculture, rooting permits plant production when seed is scarce, and in tree breeding the cloning of individual selected genotypes. This more common use of highly selected individual genotypes, which lend themselves to mass propagation, has given rise to the expectation that "clonal forestry", which is now common in hybrid poplars only, may be practiced in future on a larger scale (Swedish University of Agricultural Sciences 1981, Zsuffa et al. 1985).

Clonal propagation has certain advantages such as the option to avoid expenditures for seed orchards when plant requirements are very limited. Another advantage is the great efficiency of clonal testing and selection (Libby 1964). Since

1Dept. of Forest Resources, Faculty of Forestry. University of New Brunswick Fredericton, N.B. E3B 6C2 all trees (= ramets) of the same clone are genetically identical, far fewer trees are needed for clonal testing than for testing of seedling families from open or controlled pollination. Russell and Libby (1986) found, that depending upon selection intensities and heritabilities, six or fewer ramets per clone are generally needed for each test location. By comparison, usually 20 to 40 seedlings per family are used. Thus smaller test areas are possible if clonal testing is adopted, or a combination of clonal and seedling tests can be used if a variety of genetic parameters is estimated that cannot be derived from clonal tests alone (Corriveau 1976).

It is very desirable that reliable rooting methods are developed in the genus Larix Mill. This genus has good potential to close the gaps in wood supply that are beginning to develop in eastern Canada, and several workshops have been held recently to review research and discuss applications (Graham et al. 1983, New Brunswick Forest Research Advisory Committee 1986). Rauter and Graham (1983) considered the genetics and tree improvement potential of the larches and suggested that clonal testing and selection could have a role to play in such improvement. Park and Fowler (1982) found large specific combining ability variances for early height in tamarack (Larix laricina [Du Roi] K. Koch) and suggested that vegetative propagation may be necessary to capture non-additive genes. In view of the difficulties of seed collection in tamarack, Farmer et al. (1986) showed how wildings transplanted from natural stands could serve as ortets for the rooting of clones and establishment of a provenance experiment. 
Experiments to root cuttings of tamarack have been conducted at the University of New Brunswick since 1981. The objective of these experiments was to develop techniques that could be used in a clonal selection program based on young wild stands when improvement of stem form and height growth is attempted in the first generation. Factors considered were age of parent tree, timing (season) of the rooting operation, and facilities for rooting and overwintering. This paper will review and integrate results obtained from several experiments reported earlier (Morgenstern and Nicholson 1982, Morgenstern et al. 1984, Pottinger 1985 , Pottinger and Morgenstern 1985), and will add information on overwintering and facilities.

\section{Materials and Methods}

A detailed description of methods used is given in the papers cited and under the individual topics below. Here only general procedure, common to all experiments, will be described.

Individual trees (ortets) were selected in young natural stands or plantations during the growing season, preference being given to straight, vigorous trees. Cuttings $6-10 \mathrm{~cm}$ long were removed over the whole tree or parts of the crown, depending upon the objective of the individual experiment. In the greenhouse, the cuttings were trimmed to uniform size, the lower needles cut off, the cutting dipped into water and then a rooting hormone, and then inserted into the rooting medium. The medium consisted of a 1:1 mixture of sphagnum peat and vermiculite kept in styrobloc-20 containers. Each clone was represented by five ramets in a row-plot and these plots were replicated two to four times in a completely randomized experiment. Fungicides were applied at weekly intervals and fertilizers added one month after the cuttings had been struck. Greenhouse temperatures were usually kept at $20-25^{\circ} \mathrm{C}$ but exceeded $30^{\circ} \mathrm{C}$ for short periods during hot days.

Overwintering occurred in a cool greenhouse, the nursery, shade-hall or sealed plastic greenhouse, depending upon the timing and other objectives of individual experiments. Transplanting into a nursery for one year was necessary before rooted cuttings could be planted into the field. Assessments were made three months after striking after another year in the nursery, and up to three more years in a field experiment. Characteristics assessed were percent of cuttings rooted, root length, shoot phenology, height and survival in the nursery, and height in the field. Leader development, particularly deviation from normal straight shoots (plagiotropic growth), was also noted.

\section{Effect of Age of Parent Plant}

The age of the parent plant or ortet is important. It affects not only the percentage of cuttings per individual rooted but also subsequent development. Rooting ability generally declines with age (Hartmann and Kester 1983), but this trend may be obscured by clonal variation that is present in any sample, particularly when the sample is small. Thus Carter (1984) found that cuttings from nine tamarack trees 19 to 41 years old rooted with 23 to $93 \%$ without any correlation with age.

The relationship of rooting to age, which was found in our experiments initiated in 1981, is given in Table 1. In the third year, differences between age classes were still reflected in height and statistically significant. They persisted to the fifth year but had become insignificant. The more vigorous
Table 1. Effect of parent-tree age on rooting of cuttings and growth in the nursery and field.

\begin{tabular}{lrrrrr}
\hline $\begin{array}{l}\text { Character and } \\
\text { environment }\end{array}$ & $\mathbf{3 - 4}$ & $\mathbf{5 - 6}$ & $\mathbf{7 - 8}$ & $\mathbf{9 - 1 0}$ & $\begin{array}{c}\text { Significance } \\
\text { level }^{1}\end{array}$ \\
\hline $\begin{array}{l}\text { Rooting (\%) } \\
\text { Greenhouse - Year 1 }\end{array}$ & 69 & 67 & 54 & 47 & $1 \%$ \\
$\begin{array}{l}\text { Height (cm) } \\
\text { Nursery - Year 2 }\end{array}$ & 21 & 23 & 20 & 19 & - \\
$\begin{array}{l}\text { Height (cm) } \\
\text { Field - Year 3 }\end{array}$ & 38 & 39 & 32 & 33 & $5 \%$ \\
$\begin{array}{l}\text { Height (cm) } \\
\text { Field - Year 5 }\end{array}$ & 154 & 155 & 135 & 129 & N.S. \\
\hline
\end{tabular}

Based on F-tests in the analysis of variance. Each age class was represented by 10 clones in several replications up to Year 2, and then by smaller numbers due to lower survival of some of the clones. At Year 5 the differences were no longer significant (Morgenstern et al. 1984 Pottinger 1985). Height in the nursery was not analysed.

cuttings from the younger parents also survived better Plagiotropic growth was not important in any of the clones.

The results in Table 1 are based on pooled means from several dates of striking cuttings. When this activity is timed optimally, higher values particularly in rooting can be obtained. This aspect will be discussed under the next heading.

\section{Seasonal Effects}

While cuttings taken from actively growing larch seedlings in greenhouses can be rooted at various times of the year (Larsen 1956, Fung 1978), the rooting of cuttings from trees developing under natural conditions must be carefully timed. Although John (1979) succeeded in rooting of cuttings of Larix $\times$ eurolepis Henry during the winter following certain treatments, rooting during the summer is much easier and generally preferred. Chandler (1960) rooted cuttings of several larch species and hybrids in May, June, August and September, and found that May, August and September rooting gave best results. Hartmann and Kester (1983) recommend propagation of larch under mist in late summer, using softwood cuttings from young trees.

Our first experiment in 1981 explored the problem of seasonal effects (Morgenstern et al. 1984). The results (Table 2) showed that cuttings struck on 22 July rooted better than those in late May, early July or mid-August. Since tree development varies with climate, the phenological state is more important than the actual date. On 22 July most cuttings were somewhat lignified at the base and buds were beginning to develop. Similar favorable responses in mid-or late summer have been reported by Calvert and Rauter (1979) and Wunder (1974). From his studies of Norway spruce, Holzer (1972) concluded that the root formation potential of cuttings may follow seasonal patterns of root growth in seedlings, which is high in spring before shoot extension and again in July before the second period of height growth. It is possible that $L$. laricina follows a similar pattern. Other physiological factors, such as seasonal fluctuations of carbohydrates, nitrogenous compounds and auxins, were reviewed by Rauter (1982).

\section{Rooting Facilities}

Green softwood cuttings are subject to evaporation and transpiration, and before roots are formed, may wilt and die if a high-humidity environment is not maintained. The most common solution to this problem is the installation of an 
$\overline{\text { Table 2. Effect of striking date on rooting and subsequent growth }}$ during the first year in the nursery.

\begin{tabular}{|c|c|c|c|c|c|}
\hline Character & $\begin{array}{c}23 \\
\text { May }\end{array}$ & $\begin{array}{c}3 \\
\text { July }\end{array}$ & $\begin{array}{c}22 \\
\text { July }\end{array}$ & $\begin{array}{c}14 \\
\text { Aug }\end{array}$ & $\begin{array}{c}\text { Significance } \\
\text { level }^{1}\end{array}$ \\
\hline Rooting \% & 48 & 65 & 77 & 48 & $1 \%$ \\
\hline $\begin{array}{l}\text { Total height } \\
\text { in nursery }(\mathrm{cm})\end{array}$ & 20.2 & 22.6 & 23.3 & 16.8 & - \\
\hline
\end{tabular}

'Based on F-tests in the analysis of variance (Morgenstern et al. 1984). Height in the nursery was not analysed.

automatic mist system using cyclic timers, magnetic solenoid valves and several regularly spaced mist nozzles (Hartmann and Kester 1983).

In our experiments we used plastic rooting chambers supported by light metal frames and set on top of greenhouse benches (Fig. 1). Since all cuttings were struck in the summer, bottom heat was not needed. Control of intermittent misting was achieved either by the "electronic leaf" mechanism or the screen balance as described by Hartmann and Kester (1983: 331). We found the screen balance to be more effective and simpler to operate and maintain than either the "electronic leaf" or pre-set regular timers. Its capacity to automatically react to changes in weather is its greatest asset.

In some situations the control of humidity is possible by simpler means. Experience in Ontario has shown that socalled "mini-greenhouses" consisting of simple wooden frames and plastic sheets set up inside larger plastic or fibre glass greenhouses with effective temperature control have been sufficient. Such structures make misting inside these "mini-greenhouses" systems unnecessary and simplify the operation; watering and aeration can be done by hand once or twice daily (Armson et al. 1980). At the Strathlorne Nursery of the Nova Scotia Department of Lands and Forests in Cape Breton Island, a practical system for operational rooting is used. It consists of a large greenhouse with shade curtains, continuous vent air intake and sequenced exhaust fans. Fogging nozzles are mounted on irrigation booms. The system allows control of temperature to remain at about $22^{\circ} \mathrm{C}$ and relative humidity at $75 \%$ (pers. comm., Mr. B. White; Levy 1983).

For experimental work Dr. G. Vallée of Québec Ministère de l'Energie et des Ressources has designed individual

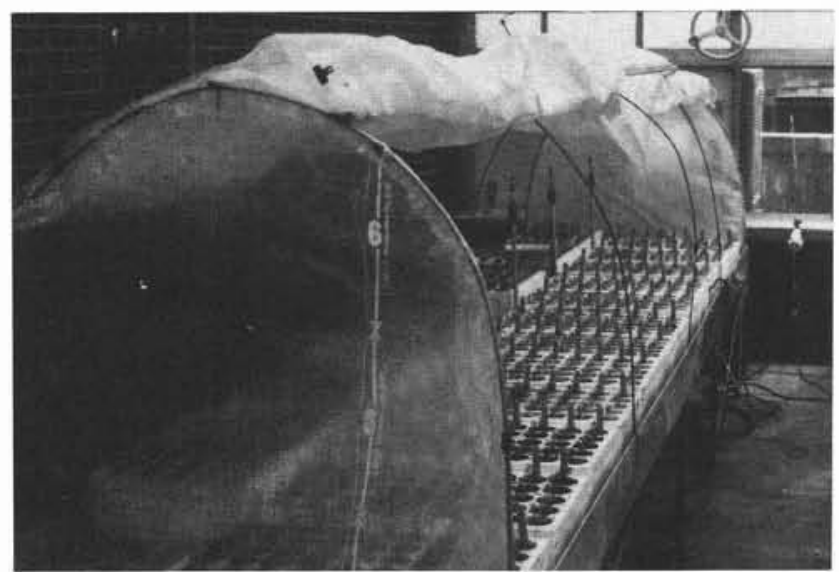

Figure 1. Rooting chamber in greenhouse showing metal frame and plastic covering. Styrobloc containers and misting nozzles are visible inside. cabinets with glass walls and fluorescent lights. The lights provide ideal temperature and light conditions and the closed walls and cover maintain a high humidity. The cabinets must be placed inside greenhouses or other rooms that will maintain favourable external temperature (pers. comm., Dr. Vallée).

\section{Overwintering}

The question of overwintering is important, particularly in larches, which, when rooted at the optimum time in late July cannot be transplanted into the nursery before the fall frost. It would be possible to grow rooted cuttings throughout the winter but this requires larger containers, or poor shoot-root ratios will develop. We assumed that overwintering in another environment will generally be preferred to avoid the expenditure for heated greenhouse space. Therefore a hardening-off treatment must be designed and an overwintering environment created. Because of their small and fragile roots, cuttings are more susceptible than seedlings at that stage to extremes of moisture, wind and cold temperature. Although overwintering of containerized seedlings could be used as a guide (Hallett 1982, Tinus 1982), it was not known whether the treatments described were sufficient.

An overwintering experiment was carried out in 1984-85 that was based on 25 clones of 5-6-year-old Larix laricina selected in a natural stand near Fredericton. Twenty cuttings were taken from each tree on 24 July 1984 and struck in four replications of five cuttings each in a row-plot. The rooting hormone applied, rooting medium and irrigation were the same as indicated in past reports (Morgenstern et al. 1984), and an 18-hour photoperiod was used. The overall rooting obtained by 11 October 1984 was $86 \%$.

Following the assessment, the plastic covering of the rooting chamber was removed, the temperature in the greenhouse drastically reduced, and the photoperiod lowered to natural daylength; only the misting system was left in place. One week later the stock was moved from the University to Acadia Forest Experiment Station of the Canadian Forestry Service for hardening. The cuttings were treated with a 10-5210 fertilizer, kept in a dry and cool (minimum about $5^{\circ} \mathrm{C}$ ) greenhouse, and at natural daylength. These treatments led to cessation of growth and bud formation and many of the needles dropped during the four weeks of this treatment.

In mid-November the cuttings were moved in their styrobloc containers to three overwintering environments:

1. Two replications to an unheated, plastic greenhouse, which was watered heavily and then "sealed", i.e. closed well to reduce exchange of air and loss of moisture; it was not opened until late in February or early March when incoming radiation required that it be opened to avoid excessive increases in temperature (Fig. 2);

2. One replication into an outside shade-hall where the plants were protected by snow most of the winter;

3. The last replication into a lightly heated greenhouse ranging in temperature from about $5-10^{\circ} \mathrm{C}$, where plants were watered as required, i.e. about once or twice each week, and the photoperiod was natural daylength.

The over-winter survival of the rooted cuttings in the three environments was assessed on 17 May 1985 and the results were: 
unheated, sealed greenhouse shade-hall

$98 \%$

$100 \%$

heated greenhouse

Overwintering in the two cold environments was therefore very successful, with better survival than in the heated greenhouse. It is possible to overwinter cuttings struck in July in unheated environments, provided that the plants have hardened sufficiently.

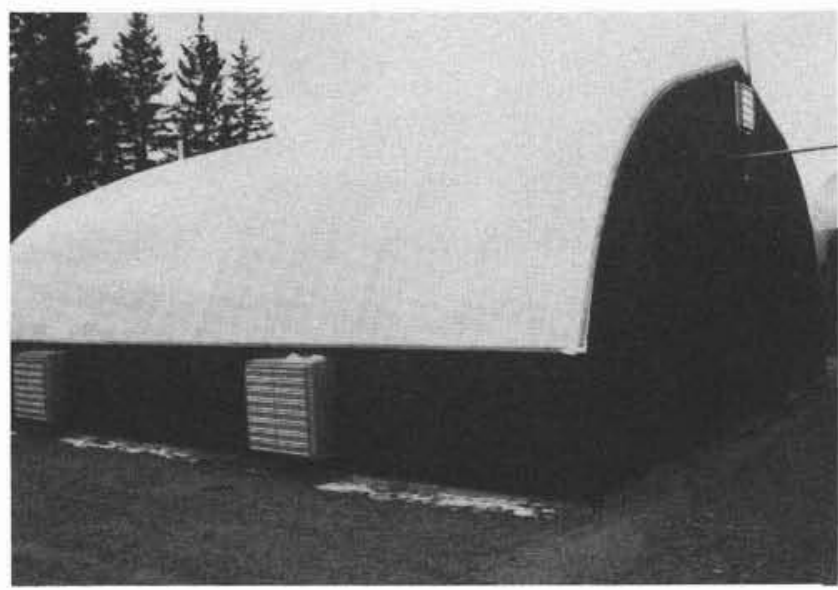

Figure 2. Sealed, unheated greenhouse at Acadia Forest Experiment Station, which was used to successfully overwinter rooted cuttings

\section{Clonal Selection}

In a clonal selection program based on rooted cuttings, it is desirable to select individuals when their qualities are fully expressed, i.e. at an age approaching or close to maturity. Unfortunately, at that age propagation is more difficult than at the juvenile stage for two reasons: (1) rootability declines with age, and (2) rooted cuttings from older or mature trees exhibit plagiotropic growth for several years or topophysis (maintain a branch orientation and character) (Roulund 1981, Rauter 1982).

Our results indicate that we may be able to cope with these two problems. In tamarack, selection is made to improve growth and stem form. Stem form in forest trees is more strongly inherited than growth (Ortmann 1961, Zobel and Talbert 1984). It appears to be fully expressed when the trees are 6 to 10 years old, particularly when the trees are growing freely, and on good sites or in plantations (Fig. 3). Therefore selection for stem form in the first stage may be effective when rootability is still acceptable and plagiotropic or topophytic growth minimal. The improvement of height and diameter on the other hand will more likely result from selection in the second stage, i.e., the clonal tests to be established (Morgenstern and Nicholson 1982). Since it is known that these growth characters are less strongly inherited, replicated and randomized experiments will assist the breeder to overcome obstacles such as unequal competition, age differences and microsite effects that mask genetic differences in wild stands. Early selection in the first stage (to improve stem form) may also be acceptable if short rotations are expected, such as periods of 25-35 years, since selection then is based on about one-fourth of a rotation period.

\section{Conclusions}

Five years of experience with tamarack rooting have provided sufficient information to guide an operational rooting

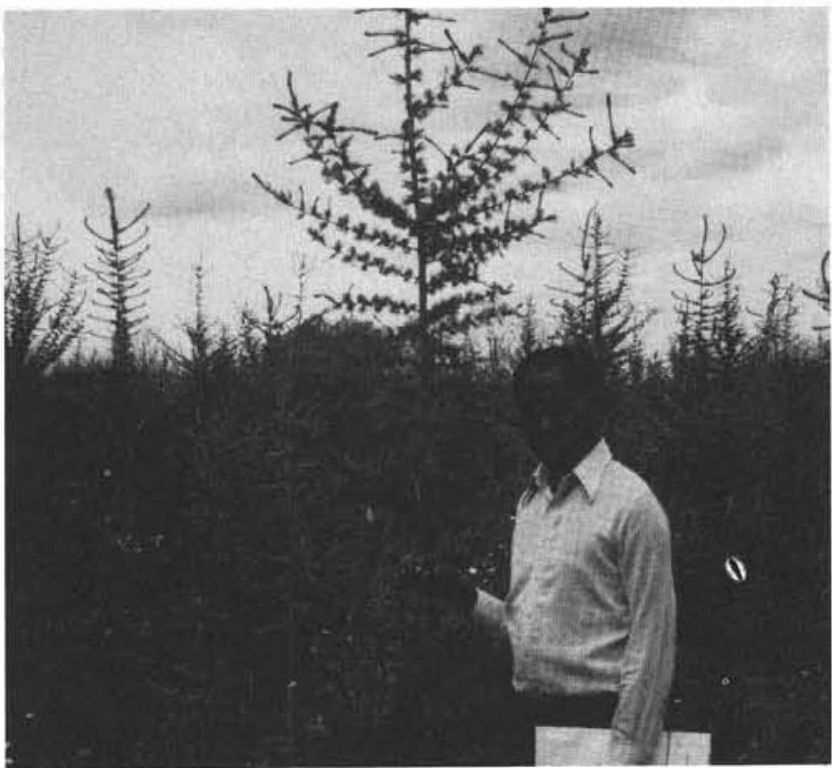

Figure 3. A straight tree selected in a tamarack plantation at the age of 6 years from seed.

program. While physiological effects of age and season have universal applicability, the rooting and overwintering facilities to be designed will depend upon the size of the program and the climate of the particular locality where the work will be done. For example, at Strathlorne, Nova Scotia, summer heat is less than at Orono, Ontario and the requirements for cooling not as great. Therefore, a general methodology (greenhouses and equipment) would have to be modified to suit local conditions of summer and winter temperature control, wind, snow pressure, and irrigation requirements.

Although our work is based only on tamarack, the literature suggests that the requirements for rooting of other species of Larix are very similar. In view of the short rotations anticipated, clonal selection in wild stands and plantations may be acceptable to initiate improvement of stem form.

\section{Acknowledgements}

Grateful acknowledgement is made to Niels Kreiberg. New Brunswick Department of Forests, Mines and Energy, for making cuttings available from a plantation at the Kingsclear Nursery; and R.D. Hallett, Canadian Forestry Service, for advice on hardening-off treatments and permission to use the facilities at Acadia Forest Experiment Station. Technical assistance was provided by J. Kielo, D. Lavigne, and especially J. Nicholson and R. LeBlanc.

\section{References}

Armson, K.A., M. Fung and W.R. Bunting. 1980. Operational rooting of black spruce cuttings. J. For. 78: 341-343.

New Brunswick Forest Research Advisory Committee. 1986.

Calvert, R.F. and R.M. Rauter. 1979. Status of larch improvement. Can. For. Serv. COJFRC Symp. Proc. O-P-7. pp. 145-152.

Carter, K.K. 1984. Rooting of tamarack cuttings. For, Sci. 30: 392394.

Chandler, C. 1960. The propagation of Larix from soft-wood cuttings. Proc. 7th Northeast. For. Tree Improv. Conf., pp. 32-39.

Corriveau, A.G. 1976. The clonal test: an aid to progeny testing and a way to speed up genetic gains. U.S. For. Serv. Gen. Tech. Rep. NC-26. pp. 167-180.

Farmer, R.E., H.A. Foster, O. Bakowski, B. MacDonald, G. O'Reilly and R. Reinholt. 1986. A vegetative propagation system for tamarack. North. J. Appl. For. 3: 91-93.

Farrar, J.L. 1939. Rooting of Norway spruce cuttings. For. Chron. 15: 152-163 
Fung, M.Y.P. 1978. Vegetative propagation of larch cuttings. M.Sc.F. thesis, Fac. of Forestry, Univ. Toronto. $113 \mathrm{pp}$.

Graham, C.M., H.L. Farintosh and B.J. Graham, Editors. 1983. Larch symposium. Potential for the future. Proceedings of a symposium sponsored by Ontario Ministry of Natural Resources and Faculty of Forestry, Univ. of Toronto, November 1982. $175 \mathrm{pp}$.

Hallett, R.D. 1982. Contrasting approaches to containerized seedling production. 3. The Maritime Provinces. Can. For. Serv, - Ont. Min. Nat. Resour. COJFRC Symp. Proc. O-P-10. pp. 129-138.

Hartmann, H.T. and D.E. Kester. 1983. Plant Propagation. 4th ed. Prentice-Hall, Englewood Cliffs, N.J. 727 pp.

Holzer, K. 1972. Pflanzgutbeschaffung von Fichte (Picea abies) für Hochlagen durch Stecklingsvermehrung. Mitt. Forstl. Bundesversuchsanst. Wien H. 96, pp. 61-73.

Kleinschmit, J. 1975. Vegetative Vermehrung der Fichte. Mitt. Verein Standortsk. U. Forstpflanzenzüchtg. 24:78-83.

John, A. 1979. Propagation of hybrid larch by summer and winter cuttings. Silvae Genet. 28: 220-225.

Larsen, C.S. 1956. Genetics in Silviculture. Oliver and Boyd, Edinburgh. 224 pp.

Levy, D.M. 1983. Production of Highland black spruce from cuttings. Nova Scotia Dept. Lands and Forests, For. Tech. Note No. 7. 4 pp.

Libby, W.J. 1964. Clonal selection and an alternative seed orchard scheme. Silvae Genet. 13: 32-40.

Morgenstern, E.K. and J.J.M. Nicholson. 1982. Clonal selection as a breeding alternative for Larix laricina. Proc. IUFRO Joint Meetg. Working Parties on Genetics about Breeding Strategies including Multiclonal Varieties. Sensenstein, Germany, 1982. Publ. by Lower Saxony For. Res. Inst., Staufenberg-Escherode, Fed. Rep. Germany. Abstract, p. 141

Morgenstern, E.K., J.M. Nicholson and Y.S. Park. 1984. Clonal selection in Larix laricina. I. Effects of age, clone and season on rooting of cuttings. Silvae Genet. 33: 155-160.

Ortmann, C. 1961. Vorläufige Untersuchungsergebnisse zur Frage der Selektionstypen für eine Frühdiagnose von Salix alba Populationen. Silvae Genet. 10: 43-48.
Park, Y.S. and D.P. Fowler. 1982. Effects of inbreeding and genetic variances in a natural population of tamarack (Larix laricina [ Du Roi ] K. Koch) in eastern Canada. Silvae Genet. 31:21-26.

Pottinger, A.J. 1985. An investigation of factors influencing the successful propagation of young tamarack stem cuttings. M.F. report, Faculty of Forestry, Univ. of New Brunswick. 67 pp.

Pottinger, A.J. and E.K. Morgenstern. 1985. Factors influencing successful propagation of young tamarack stem cuttings. Proc. 29th Northeast. For. Tree Improv. Conf., pp. 48-55.

Rauter, R.M. 1982. Recent advances in vegetative propagation including biological and economic considerations and future potential. Proc. IUFRO Joint Meetg. Working Parties on Genetics about Breeding Strategies including Multiclonal Varieties. Sensenstein, Germany, 1982. Publ. by Lower Saxony For. Res. Inst., Staufenberg-Escherode, Germany. pp. 33-57.

Rauter, R.M. and B.J. Graham. 1983. The genetics and tree improvement potential of larches in Ontario. Proceedings of a symposium sponsored by Ontario Ministry of Natural Resources and Faculty of Forestry, Univ. of Toronto, November 1982. pp. $11-26$.

Roulund, H. 1981. Problems of clonal forestry in spruce and their influence on breeding strategy. For. Abstr. 42: 457-471.

Russell, J.H. and W.J. Libby. 1986. Clonal testing efficiency: the trade-offs between clones tested and ramets per clone. Can. J. For. Res. 16: 925-930

Swedish University of Agricultural Sciences. 1981. Symposium on clonal forestry. Dept. of Forest Genetics Research Notes 32. $131 \mathrm{pp}$.

Tinus, R.W. 1982. Environmental control of seedling physiology. Can. For. Serv. - Ont. Min. Nat. Res. COJFRC Symp. Proc. O-P-10. pp. $75-82$

Wunder, W.G. 1974. Vegetative propagation of Japanese larch. N.Z.J. For. Sci. 4: 161-166.

Zobel, B. and J. Talbert. 1984. Applied Forest Tree Improvement. J. Wiley \& Sons, Toronto. 505 pp.

Zsuffa, L., R.M. Rauter and C.W. Yeatman, editors. 1985. Clonal forestry: its impact on tree improvement and our future forests. Proc. Nineteenth Meetg. Can. Tree Improv. Assoc., Part 2. 235 $\mathrm{pp}$

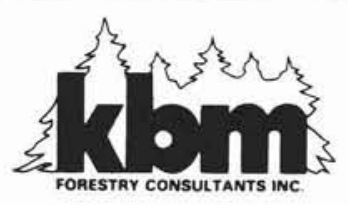

360 mooney street

thunder bay, ontario

P7B 5R4

REFORESTATION EQUIPMENT

- Sales Service Parts Repair

REGENERATION \& SITE PREPARATION

- Contract Assessment Consulting

807-344-0811 telex 073-4603 